\title{
Maintenance of sinus rhythm after atrial defibrillation
}

\author{
Paul Szekely, D. A. Sideris, and G. A. Batson \\ From the Cardiovascular Department, Newcastle General Hospital, Newcastle upon Tyne
}

The long-term results of 356 episodes of atrial defibrillation by DC shock carried out in 250 patients are reviewed.

In 78 per cent of the cases, atrial fibrillation recurred by the end of 12 months in spite of the administration of quinidine or procainamide or propranolol, singly or combined. However, when no antidysrhythmic drugs were used the recurrence rate was higher at all periods of observation and 100 per cent at the end of 12 months. The difference in the overall results between the untreated group and the treated groups with the exception of the propranolol group is significant $(p<0.05)$. In addition, the propranolol group showed an obviously reduced recurrence rate at I month, but afterwards the results tended to approximate those in the untreated group.

The period during which sinus rhythm could be maintained in patients who underwent valve operations was on the whole the same as in patients who did not have heart surgery. However, in a small number of patients sinus rhythm was maintained for longer periods after mitral valve replacement than before it.

Sinus rhythm was maintained for significantly longer periods when atrial fibrillation lasted less than I year than when it had been present for more than I year $(p<0.00 I)$.

It is concluded that there is justification for a judicious antidysrhythmic prophylaxis after atrial defibrillation.

Since the introduction of direct current (DC) shock in the treatment of ectopic tachycardias (Lown, Amarasingham, and Neuman, 1962; Oram et al., 1963), numerous reports have appeared confirming the view that it is the most effective method of terminating atrial fibrillation and restoring sinus rhythm. However, experience has shown that the favourable immediate results (between 80 and $90 \%$ ) contrast sharply with the difficulty in maintaining sinus rhythm for longer periods. In previous communications (Szekely et al., 1969, 1970), we assessed the advantages and potential hazards of using antidysrhythmic drugs concomitantly with DC shock in atrial fibrillation. In the present communication, our aim is to evaluate the long-term use of antidysrhythmic drugs in maintaining sinus rhythm after electroconversion of atrial fibrillation.

\section{Methods and clinical groups}

Between December 1963 and December 1968, 457 episodes of atrial fibrillation occurring in 318 patients were treated by DC shock. Sinus rhythm

Received 4 February 1970. was restored on 389 occasions ( $85 \%$ ). In 27 cases atrial fibrillation recurred within 24 hours. Six patients could not be traced for follow-up study. Thus, the long-term results of 356 episodes of atrial defibrillation carried out in 250 patients were available for analysis. Two hundred patients had rheumatic heart disease, 22 coronary artery disease, 4 congenital heart disease, Io thyrotoxicosis, and I4 patients 'lone' atrial fibrillation, several of whom were suspected to have cardiomyopathy. The follow-up period ranged from I to 5 years. Antidysrhythmic agents such as quinidine sulphate, a long-acting quinidine preparation (kinidin durules), procainamide, and propranolol were used singly or in combination on 337 occasions in an attempt to prevent recurrences of atrial fibrillation, and on 19 occasions no antidysrhythmic agents were given during the follow-up period. The drugs were started as a rule 3 to 5 days before electroconversion and continued without interruption with occasional variation in the dosage until atrial fibrillation recurred. However, in August 1968 we stopped giving routinely antidysrhythmic drugs before elective electroconversion and started their use within 24 hours after restoration of sinus rhythm. The last 12 patients included in this series were treated this way. Except in the very early cases, digitalis was discontinued 3 to 5 days before electroconversion, 
TABLE I Antidysrhythmic drug therapy after atrial defibrillation by direct current shock

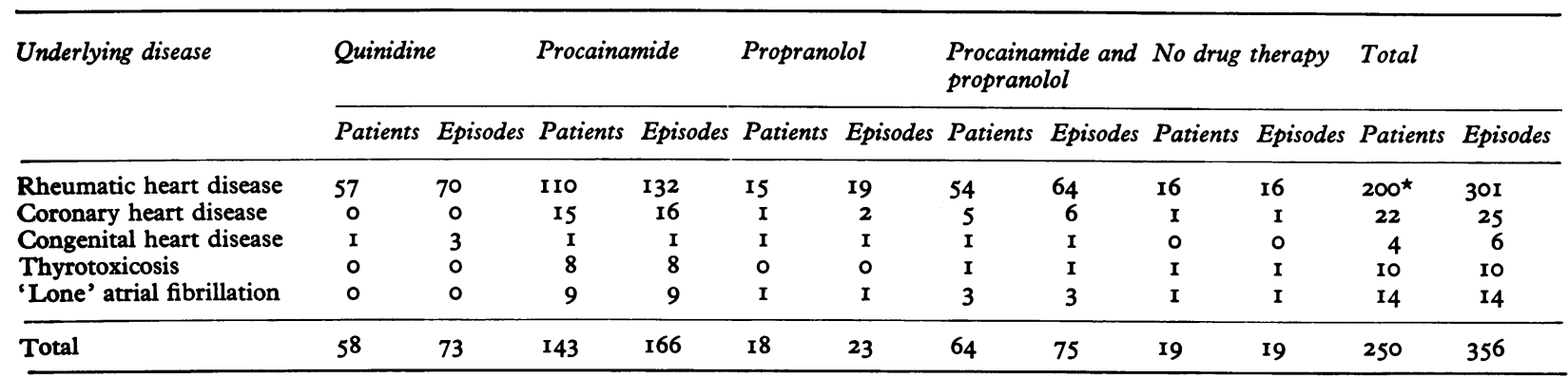

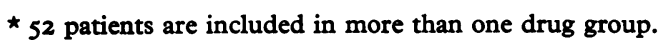

and restarted 24 hours after DC shock, $0.25 \mathrm{mg}$. daily. Serum quinidine levels were estimated according to the method of Brodie and Udenfriend (1943).

\section{Results}

The number of patients studied in relation to the underlying pathology and type of antidysrhythmic treatment is shown in Table $I$, and the results are summarized in Table 2.

Quinidine On 5 occasions, quinidine sulphate was given, I g. daily, and on 68 occasions a long-acting quinidine preparation (kinidin durules) $\mathbf{I} \cdot \mathbf{2} \mathrm{g}$. daily in divided doses. Atrial fibrillation recurred at $I$ month in 23 instances (32\%), at 3 months in 40 instances $(55 \%)$, and at the end of 12 months in 56 instances $(\mathbf{7 7} \%)$.

A total of 353 serum quinidine level estimations carried out at 4 to 8 weeks' intervals was available for correlation with the cardiac rhythm. Three hundred and seven serum quinidine estimations were made while sinus rhythm was maintained, giving an average serum quinidine level of $5.6 \mathrm{mg}$. $/ 1$., and 46 estimations were made on the day or within 72 hours of recurrence of atrial fibrillation, giving an average serum quinidine level of $2.9 \mathrm{mg}$./1. However, on 3 occasions atrial fibrillation recurred at serum quinidine levels of $9.3,6.6$, and $6.3 \mathrm{mg} . / 1$. , respectively (Table 3).

Procainamide One hundred and fortythree patients received procainamide $3 \mathrm{~g}$. daily in divided doses on 166 occasions after the restoration of sinus rhythm. Atrial fibrillation recurred at $I$ month in 57 instances $(34 \%)$, at 3 months in 87 instances $(52 \%)$, and at the end of 12 months in 125 instances $(75 \%)$.

Propranolol Eighteen patients received on
TABLE 2 Recurrence of atrial fibrillation after restoration of sinus rhythm by DC shock in relation to antidysrhythmic drug therapy

\begin{tabular}{|c|c|c|c|c|c|c|c|}
\hline \multirow[t]{3}{*}{ Drug therapy } & \multirow{3}{*}{$\begin{array}{l}\text { No. of } \\
\text { cases }\end{array}$} & \multicolumn{6}{|c|}{ Recurrence of atrial fibrillation } \\
\hline & & \multicolumn{2}{|c|}{$I$ month } & \multicolumn{2}{|c|}{3 months } & \multicolumn{2}{|c|}{12 months } \\
\hline & & No. & $\%$ & No. & $\%$ & No. & $\%$ \\
\hline $\begin{array}{l}\text { Quinidine } \\
\text { Procainamide } \\
\text { Propranolol } \\
\text { Procainamide and propranolol } \\
\text { No drug therapy }\end{array}$ & $\begin{array}{r}73 \\
166 \\
23 \\
75 \\
19\end{array}$ & $\begin{array}{r}23 \\
57 \\
9 \\
24 \\
13\end{array}$ & $\begin{array}{l}32 \\
34 \\
39 \\
32 \\
68\end{array}$ & $\begin{array}{l}40 \\
87 \\
16 \\
43 \\
16\end{array}$ & $\begin{array}{l}55 \\
52 \\
70 \\
57 \\
84\end{array}$ & $\begin{array}{r}56 \\
125 \\
20 \\
59 \\
19\end{array}$ & $\begin{array}{l}77 \\
75 \\
87 \\
79 \\
100\end{array}$ \\
\hline Total & 356 & 126 & 35 & 202 & 57 & 279 & 78 \\
\hline
\end{tabular}

23 occasions propranolol, $60 \mathrm{mg}$. daily in divided doses.

Atrial fibrillation recurred at I month in 9 instances (39\%), at 3 months in 16 instances $(70 \%)$, and at the end of 12 months in 20 instances $(87 \%)$.

Procainamide and propranolol Sixtyfour patients received on 75 occasions procainamide $2 \mathrm{~g}$. daily and propranolol between

TABLE 3 Mean serum quinidine levels during maintenance of sinus rhythm and at recurrence of atrial fibrillation

\begin{tabular}{lclc}
\hline $\begin{array}{l}\text { Serum } \\
\text { quinidine } \\
\text { levels } \\
\text { (mg.|l.) }\end{array}$ & $\begin{array}{l}\text { Sinus } \\
\text { rhythm } \\
\text { maintained } \\
\text { No. of tests }\end{array}$ & $\begin{array}{l}\text { Atrial } \\
\text { fibrillation } \\
\text { recurred } \\
\text { No. of tests }\end{array}$ & Total \\
\hline$<2$ & I & 13 & 14 \\
$2-2 \cdot 9$ & 22 & 17 & 39 \\
$3-3 \cdot 9$ & 36 & 9 & 45 \\
$4-4 \cdot 9$ & 61 & 4 & 65 \\
$5-5 \cdot 9$ & 83 & 0 & 83 \\
$6-6 \cdot 9$ & 53 & 2 & 55 \\
$7-7 \cdot 9$ & 33 & 0 & 33 \\
$8-8 \cdot 9$ & 12 & 0 & 12 \\
$9-9 \cdot 9$ & 6 & 1 & 7 \\
\hline Total & 307 & 46 & 353 \\
\hline
\end{tabular}


30 and $60 \mathrm{mg}$. daily. Atrial fibrillation recurred at I month in 24 instances ( $32 \%$ ), at 3 months in 43 instances $(57 \%)$, and at the end of 12 months in 59 instances $(79 \%)$.

No drug therapy Nineteen patients received on 19 occasions no antidysrhythmic drugs at all (except digoxin $0.25 \mathrm{mg}$. daily). Atrial fibrillation recurred at 1 month in 13 instances $(68 \%)$, at 3 months in 16 instances $(84 \%)$, and at the end of 12 months in 19 instances $(100 \%)$.

Six of these patients received quinidine or procainamide after subsequent episodes of atrial defibrillation. On these occasions, atrial fibrillation recurred at $I$ month in none, at 3 months in $3(50 \%)$, and at the end of 12 months in $4(66 \%)$. The 2 other patients maintained sinus rhythm for 14 months and 28 months, respectively.

Recurrence of atrial fibrillation in relation to underlying pathology

The results are summarized in Table 4.

Rheumatic heart disease The long-term results of 301 episodes of atrial defibrillation in 200 patients were studied in this group. Atrial fibrillation recurred at I month in 109 instances $(36 \%)$, at 3 months in 170 instances $(56 \%)$, and at the end of 12 months in 240 instances $(80 \%)$.

When the patients were divided into those in whom atrial defibrillation was carried out after cardiovascular surgery (surgical group) and those who had not undergone cardiac surgery (medical group), the recurrence rate differed but little in the 2 groups, being 38 per cent and 33 per cent at I month, 60 per cent and 52 per cent at 3 months, and 79 per cent and 8I per cent, respectively, at 12 months. In all the patients included in the surgical group atrial fibrillation either preceded cardiac surgery or started years after it. This series does not include patients who first developed atrial fibrillation immediately after cardiac surgery.

In a total of 19 patients, atrial fibrillation was treated by DC shock before and also after cardiac surgery. Of these, II patients had closed mitral valvotomy, 7 had mitral valve replacement, and I had aortic valve replacement. In the II patients who had mitral valvotomy, sinus rhythm was restored on II occasions before operation, and it was maintained for an average of 4 months. After cardiac surgery, sinus rhythm could not be restored in $I$ of these patients, in 3 patients atrial fibrillation recurred within 24 hours, and in the remaining 7 patients sinus rhythm
TABLE 4 Recurrence of atrial fibrillation after restoration of sinus rhythm by $D C$ shock in relation to underlying pathology

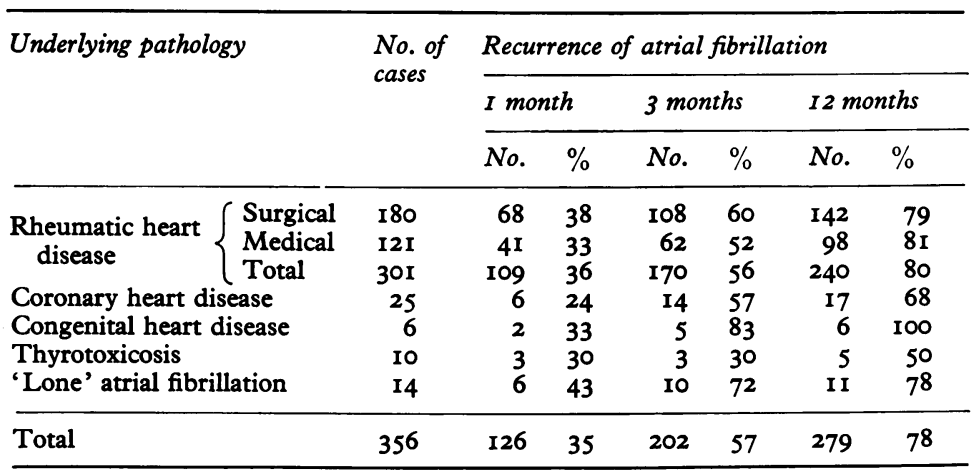

was maintained for an average of 4.5 months. All 7 patients were on antidysrhythmic drugs.

Of the 7 patients who had mitral valve replacement, in I sinus rhythm could not be restored before or after cardiac surgery. In the other 6 patients sinus rhythm was restored before cardiac surgery and it was maintained for an average period of 6 months. After cardiac surgery, sinus rhythm was again restored in these 6 patients and normal rhythm was maintained for an average period of ro months, with only I of these 6 patients still maintaining sinus rhythm at the time of writing. All 6 patients were on antidysrhythmic drugs.

In the patient who had aortic valve replacement, sinus rhythm was maintained for I month before cardiac surgery and 4 months after it.

Coronary disease This group contains 25 episodes of atrial defibrillation carried out in 22 patients. Atrial fibrillation recurred at I month in 6 instances $(24 \%)$, at 3 months in 14 instances $(57 \%)$, and at the end of 12 months in 17 instances $(68 \%)$.

Congenital heart disease There were 6 episodes of atrial defibrillation in 4 patients. Atrial fibrillation recurred at I month in 2 instances $(33 \%)$, at 3 months in 5 instances $(83 \%)$, and at the end of 12 months in 6 instances $(100 \%)$.

Thyrotoxicosis Ten episodes of atrial defibrillation in ro patients were studied in this group. Atrial fibrillation recurred at I month in 3 patients $(30 \%)$, remaining unchanged at 3 months $(30 \%)$, and at the end of 12 months in 5 patients $(50 \%)$.

Lone atrial fibrillation Fourteen episodes 
of atrial defibrillation in 14 patients were included. Atrial fibrillation recurred at I month in 6 instances $(43 \%)$, at 3 months in Io instances $(72 \%)$, and at the end of 12 months in II instances (78\%).

\section{Recurrence of atrial fibrillation in rela-} tion to its duration before DC shock

The data are summarized in Table 5.

The recurrence rate of atrial fibrillation was significantly higher at all periods of observation when atrial fibrillation lasted more than one year before restoration of sinus rhythm than when it lasted less than one year. Thus, atrial fibrillation recurred in the former group of I94 cases at I month in 86 instances $(48 \%)$, at 3 months in 137 instances ( $71 \%)$, and at the end of 12 months in 175 instances $(90 \%)$. The corresponding figures of recurrences in the latter group of 162 cases were at I month 40 instances $(25 \%)$, at 3 months 65 instances $(40 \%)$, and at the end of I2 months 104 instances (65\%).

Clinical features in patients who maintained sinus rhythm for longer than 12 months

In 77 patients ( $22 \%$ ), sinus rhythm was maintained for periods longer than 12 months following atrial defibrillation; 6I had rheumatic heart disease, 38 in the surgical group and 23 in the medical group. In the surgical group, 19 of 38 patients reverted to atrial fibrillation between $I$ and 2 years, a further 6 between 2 and 3 years, and $I$ between 3 and 4 years. Of the 12 patients in sinus rhythm at the time of writing, 8 have been followed up for 2 years, 2 for 3 years, and 2 for 4 years. In the medical group, 12 of the 23 patients reverted to atrial fibrillation between $I$ and 2 years, I between 2 and 3 years, 2 between 3 and 4 years, and $I$ between 4 and 5 years. Of the 7 patients in sinus rhythm at the time of writing, 5 have been followed up for 2 years and 2 for 3 years.

The non-rheumatic groups contained only I6 patients and some of them could not be traced after 12 months so that no valid figures can be given.

\section{Discussion}

Our data show that in spite of the use of antidysrhythmic drugs about three-quarters of the patients reverted to atrial fibrillation within 12 months of restoration of sinus rhythm. However, when no antidysrhythmic drugs were given the recurrence rate was higher at all periods of follow-up observation and roo per cent at 12 months. Though the untreated group was comparatively small, the difference
TABLE 5 Recurrence rate of atrial fibrillation in relation to its duration before DC shock

\begin{tabular}{|c|c|c|c|c|c|c|c|c|}
\hline \multirow{3}{*}{\multicolumn{2}{|c|}{$\begin{array}{l}\text { Duration of atrial } \\
\text { fibrillation before } \\
\text { conversion }\end{array}$}} & \multirow{4}{*}{$\begin{array}{l}\begin{array}{l}\text { No. } \\
\text { of } \\
\text { cases }\end{array} \\
162\end{array}$} & \multicolumn{6}{|c|}{ Recurrence of atrial fibrillation } \\
\hline & & & \multicolumn{2}{|c|}{$I$ month } & \multicolumn{2}{|c|}{3 months } & \multicolumn{2}{|c|}{12 months } \\
\hline & & & No. & $\%$ & No. & $\%$ & No. & $\%$ \\
\hline$<$ I year & & & 40 & 25 & 65 & 40 & 104 & 65 \\
\hline \multirow[t]{2}{*}{$>$ I year } & $\begin{array}{l}\text { I-2 years } \\
>2 \text { years } \\
\text { Total }\end{array}$ & $\begin{array}{r}67 \\
127 \\
194\end{array}$ & $\begin{array}{l}21 \\
65 \\
86\end{array}$ & $\begin{array}{l}31 \\
50 \\
48\end{array}$ & $\begin{array}{r}40 \\
97 \\
137\end{array}$ & $\begin{array}{l}60 \\
77 \\
71\end{array}$ & $\begin{array}{r}53 \\
122 \\
175\end{array}$ & $\begin{array}{l}79 \\
96 \\
90\end{array}$ \\
\hline & Total & 356 & 126 & 35 & 202 & 57 & 279 & 78 \\
\hline
\end{tabular}

in the overall results between the untreated group and the treated groups with the exception of the propranolol group was significant $(p<0.05)$. In addition, the propranolol group showed an obviously reduced recurrence rate at I month, but afterwards the results tended to approximate those in the untreated group. The long-term results with quinidine and procainamide were similar. The treated and untreated groups were comparable regarding underlying pathology and duration of atrial fibrillation before conversion.

In patients receiving quinidine the mean serum quinidine level was found to be significantly higher when sinus rhythm was maintained than when atrial fibrillation recurred, $5.6 \mathrm{mg}$. $/ 1$. and $2.9 \mathrm{mg}$./1., respectively $(p<0.01)$. However, the clinical significance of this finding may be limited to some extent by the fact that there were important variations in the serum quinidine levels in the individual patient, and that atrial fibrillation recurred occasionally at comparatively high serum quinidine levels. The serum quinidine level not uncommonly dropped suddenly without changing the prescribed dosage, which must have been due either to interference with absorption or to failure of taking quinidine regularly. Nevertheless, the findings suggest that a serum quinidine level less than $4 \mathrm{mg}$./1. has no protective effect. This probably applies to procainamide medication as well. We have not estimated the serum procainamide concentrations, but a recent report suggests that the effective plasma procainamide concentration for suppressing dysrhythmias is 4 to $6 \mathrm{mg}$./1. (Koch-Weser $e t$ al., 1969). It is possible that more regular estimations of serum concentrations of an antidysrhythmic drug and at shorter intervals with appropriate adjustments of dosage could lead to better results.

In the series of Killip and Yormak (1965), 60 per cent of the patients in whom sinus 
rhythm was restored maintained normal rhythm at I month, and 27 per cent at I year. Their patients were receiving quinidine or procainamide. Hills and Humphries (1967) observed a relapse rate of atrial fibrillation at I, 2 , and 3 years of the order of 72,88 , and 93 per cent, respectively, but they do not mention whether the patients were receiving antidysrhythmic drugs. Bjerkelund and Orning (1968) found a 7I per cent recurrence rate of atrial fibrillation at 12 months in patients on quinidine treatment. Radford and Evans (1968) reported an overall relapse rate of 82 per cent at 12 months. Their patients on quinidine showed a lower relapse rate at $I$ and 3 months than those without antidysrhythmic prophylaxis, but the authors discontinued quinidine after 5 months or even earlier because of unfavourable reactions. Åberg and Cullhed (1968) found that 22 per cent of all those converted to sinus rhythm remained in normal rhythm after I year, and of 97 patients who received adequate quinidine treatment 27 per cent remained in sinus rhythm after 3 months. Resnekov et al. (1969) used patients as their own controls, and observed that the mean duration of sinus rhythm after atrial defibrillation was 3.8 months without quinidine and $7 \cdot 1$ months with quinidine. McCarthy, Varghese, and Barritt (1969) found, using no antidysrhythmic drugs before or after electroconversion, that of 52 patients in whom sinus rhythm was restored, 29 developed atrial fibrillation again at 6 months, and 40 before the end of I year.

Beta-adrenergic blockade alone has been previously reported as being ineffective in preventing recurrences of atrial fibrillation (Tsolakas, Davies, and Oram, 1964; Hillestad and Andersen, 1969).

In our rheumatic group, the long-term results were the same in the surgical and medical groups, a recurrence rate at 12 months of 79 and 81 per cent, respectively. According to Selzer et al. (1965), the chances of permanent restoration of sinus rhythm in established atrial fibrillation after mitral valve surgery are approximately $I$ in 5 . In a subsequent communication they stated that the immediate results were the same in mitral valve repair and valve replacement, but there appeared to be a slightly higher incidence of lasting success in patients with valve replacement (Selzer et al., 1966). In the series of Kahn et al. (1967) consisting of 55 patients who had mitral valve replacement or open mitral valvuloplasty, sinus rhythm was restored in 43 but maintained in only 12 for more than I year. A berg and Cullhed (1968) also found a high frequency of relapse in operated mitral stenosis. With our so far small number of patients in whom atrial defibrillation has been carried out after valve replacement, we are as yet not in a position to assess the longterm results.

Colin et al. (1968) were of the opinion that electrocardiographic evidence of severe left atrial hypertrophy with intra-atrial block predisposed to early recurrence of atrial fibrillation. However, they also stated that discontinuation of quinidine treatment was an important factor responsible for recurrences.

The duration of atrial fibrillation before conversion to sinus rhythm did influence the recurrence rate of atrial fibrillation; it was significantly higher when atrial fibrillation lasted more than I year before restoration of sinus rhythm than when it lasted less than I year $(p<0.00 r)$. These findings are in agreement with previously reported observations (Hills and Humphries, 1967; Resnekov and McDonald, 1968; Bjerkelund and Orning, 1968). Hills and Humphries (1967) also stated that an important factor which favoured maintenance of sinus rhythm was conversion accomplished with 200 joules or less. We found no direct correlation between the energy value used and the maintenance of sinus rhythm. It is interesting that of the $\mathbf{3 2}$ patients in the series of Aberg and Cullhed (I968) who maintained sinus rhythm for more than I year, 9 required 400 joules for conversion.

In a previous paper we referred to the potentiation by DC shock of the cardiotoxicity of antidysrhythmic drugs, and indeed we observed 2 episodes of ventricular fibrillation following combined quinidine and DC shock treatment (Szekely et al., 1970). On the other hand, the continuous administration of quinidine or other antidysrhythmic agents after uncomplicated DC shock therapy has not been responsible in this series for cardiotoxic effects or any serious extracardiac complications. Nevertheless, the potential cardiotoxicity of quinidine alone has been well documented (Selzer and Wray, 1964; Davies, Leak, and Oram, 1965). It is possible, though conjectural, that the cardiotoxicity of procainamide is less severe. An important extracardiac complication of procainamide is now known to be lupus erythematosus (Fakhro, Ritchie, and Lown, 1967). We have not observed an overt procainamide-induced lupus syndrome in any of our patients, but since the introduction of routine laboratory checks we have encountered a positive fluorescence antibody test for antinuclear factor in 5 patients, and in one of these lupus cells were found. 
We believe that there is a place for the judicious use of antidysrhythmic drugs after atrial defibrillation, though admittedly the overall advantage of such a prophylactic regimen is limited. More careful adjustment of dosage schedules may perhaps result in maintenance of sinus rhythm for longer periods than hitherto achieved. The potential risks of the long-term use of antidysrhythmic drugs have to be balanced against their likely therapeutic advantages. In accordance with our previous observations (Szekely et al., I970), and those reported by others (Åberg, 1969), our present policy is not to give antidysrhythmic drugs as pretreatment for elective electroconversion, and if conversion takes place without unwanted effects, to start antidysrhythmic prophylaxis within 24 hours after DC shock therapy.

Our thanks are due to Drs. W. J. A. Swan, F. Jackson, and C. B. Henderson, for allowing us to include many of their patients in this study. We should also like to thank Dr. A. Cassells-Smith, Department of Biochemistry, Newcastle General Hospital, for the serum quinidine estimations, the Pharmaceuticals Division, Imperial Chemical Industries Ltd., for supplies of propranolol, and Astra Chemicals Ltd., for supplies of kinidin durules.

\section{References}

Åberg, H. (1969). Quinidine prior to direct current countershock-a medical hazard. Acta Medica Scandinavica, 186, 157.

- , and Cullhed, I. (1968). Direct current conversion of atrial fibrillation-Long-term results. Acta Medica Scandinavica, 184, 433.

Bjerkelund, C., and Orning, O. M. (I968). An evaluation of DC shock treatment of atrial arrhythmias. Acta Medica Scandinavica, 184, 481.

Brodie, B. B., and Udenfriend, S. (1943). The estimation of quinine in human plasma with a note on the estimation of quinidine. Fournal of Pharmacology and Experimental Therapeutics, 78, 154.

Colin, J.-M., Sagardiluz, J., Besse, P., Broustet, J.-P., Bricaud, H., and Broustet, P. (1968). Résultats éloignés de la réduction électrique de 313 fibrillations auriculaires. Archives des Maladies du Coeur et des Vaisseaux, 61, 244.

Davies, P., Leak, D., and Oram, S. (1965). Quinidineinduced syncope. British Medical fournal, 2, 517.

Fakhro, A. M., Ritchie, R. F., and Lown, B. (1967). Lupus-like syndrome induced by procainamide. American fournal of Cardiology, 20, 367.

Hillestad, L., and Andersen, A. (I969). Beta-receptor blockade in maintenance of sinus rhythm obtained by electroconversion. Acta Medica Scandinavica, 185,535 .

Hills, J. D., and Humphries, J. O’N. (1967). Threeyear follow-up of patients electroconverted to normal sinus rhythm. Circulation, 36, Suppl. II, p. 143.

Kahn, D. R., Kirsh, M. M., Ferguson, P. W., and Sloan, H. (1967). Cardioversion after mitral valve operations. Circulation, 35, Suppl. I, p. 82.

Killip, T., and Yormak, S. (1965). Short- and longterm results from direct-current conversion for atrial fibrillation and flutter. Circulation, 32, Suppl. II, p. 125 .

Koch-Weser, J., Klein, S. W., Foo-Canto, L. I., Kastor, J. A., and DeSanctis, R. W. (1969). Antiarrhythmic prophylaxis with procainamide in acute myocardial infarction. New England fournal of Medicine, 281, 1253.

Lown, B., Amarasingham, R., and Neuman, J. (1962). New method for terminating cardiac arrhythmias. Use of synchronized capacitor discharge. Fournal of the American Medical Association, 182, 548.

McCarthy, C., Varghese, P. J., and Barritt, D. W. (1969). Prognosis of atrial arrhythmias treated by electrical counter shock therapy; a three-year follow-up. British Heart fournal, 31, 496.

Oram, S., Davies, J. P. H., Weinbren, I., Taggart, P., and Kitchen, L. D. (1963). Conversion of atrial fibrillation to sinus rhythm by direct-current shock. Lancet, 2, 159.

Radford, M. D., and Evans, D. W. (1968). Long-term results of DC reversion of atrial fibrillation. British Heart fournal, 30, 91.

Resnekov, L., and McDonald, L. (1968). Appraisal of electroconversion in treatment of cardiac dysrhythmias. British Heart fournal, 30, 786.

-, Waich, S., Gibson, D., and McDonald, L. (I969). Use of long-acting quinidine in maintaining sinus rhythm after electroconversion of atrial dysrhythmias. In Proceedings of The British Cardiac Society. British Heart Fournal, 31, 395.

Selzer, A., Kelly, J. J., Jr., Gerbode, F., Kerth, W. J., Blackley, J. E., Morgan, J. J., and Keyani, K. (1965). Treatment of atrial fibrillation after surgical repair of the mitral valve. Annals of Internal Medicine, 62, 1213.

, - Johnson, R. B., and Kerth, W. J. (1966). Immediate and long-term results of electrical conversion of arrhythmias. Progress in Cardiovascular Diseases, 9, 90.

$\longrightarrow$, and Wray, H. W. (1964). Quinidine syncope. Paroxysmal ventricular fibrillation occurring during treatment of chronic atrial arrhythmias. Circulation, 30, 17.

Szekely, P., Wynne, N. A., Pearson, D. T., Batson, G. A., and Sideris, D. A. (1969). Direct current shock and digitalis: a clinical and experimental study. British Heart fournal, 31, 91.

$\longrightarrow,-,-,-$, and - (1970). Direct current shock and antidysrhythmic drugs. British Heart fournal, 32, 209.

Tsolakas, T. C., Davies, J. P. H., and Oram, S. (1964). Propranolol in attempted maintenance of sinus rhythm after electrical defibrillation. Lancet, 2, 1064. 